\title{
Originalien
}

\section{Fatal Lymphoproliferation and Acute Monocytic Leukemia-like Disease Following Infectious Mononucleosis in the Elderly*}

\author{
R. Hehlmann ${ }^{1}$, B. Walther ${ }^{1}$, N. Zöllner ${ }^{1}$, H. Wolf ${ }^{2}$, F. Deinhardt ${ }^{2}$, and M. Schmid \\ 1 Medizinische Poliklinik der Universität München \\ ${ }^{2}$ Max-von-Pettenkofer-Institut der Universität München \\ ${ }^{3}$ Medizinische Klinik, Stadtspital Waid, Zürich
}

\begin{abstract}
Summary. Three elderly patients are reported, in whom serologically confirmed recent infectious mononucleosis is followed by fatal lymphoproliferation (case 1), by acute monocytic leukemia (case 2), and by acute probably monocytic leukemia (case 3 ).
\end{abstract}

Key words: Infectious mononucleosis - EB virus infection - Acute monocytic leukemia - Fatal lymphoproliferation

\section{Lymphoproliferative Erkrankung und akute Monozytenleukämie nach infektiöser Mononukleose im Alter}

Zusammenfassung. Es wird über drei ältere Patienten berichtet, bei denen auf serologisch gesicherte, frische infektiöse Mononukleose eine tödlich verlaufende lymphoproliferative Erkrankung (Fall 1), eine akute Leukämie vom monozytären Differenzierungstyp (Fall 2) und eine akute Leukämie von wahrscheinlich monozytärem Differenzierungstyp (Fall 3) folgt.

Schliisselwörter: Infektiöse Mononukleose - EBVirus-Infektion - akute Monozytenleukämie Lymphoproliferation

\section{Introduction}

Infectious mononucleosis is a usually self-limited lymphoproliferative disease caused by the Epstein-Barr Virus (EBV) (Henle et al. 1968). The basis for its self-limiting course appear to be intense antibody and cellular reactions to EBV-infected B-lymphocytes (Carter 1975; Purtilo 1980). The antibodies include EBV-associated and heterophil antibodies. The cellu-

* Part of this work was supported by the Deutsche Forschungsgemeinschaft (SFB51)

Offprint requests to: PD Dr. R. Hehimann (address see page 483) lar response is comprised of a large and sustained $\mathrm{T}$-cell response to an initial small increase in EBVinfected B-cells (Pattengale 1974; Mangi et al. 1974). This immune response is associated with a raise of immunoglobulins especially of the IgM class. In spite of its usually benign course fatal cases of infectious mononucleosis may occur due to mechanical (splenic rupture, Aung et al. 1978), neurological, or other complications (Penman 1970; Grose et al. 1975).

In immunodeficient persons infectious mononucleosis may run a fulminating, frequently fatal course with non-proliferative (aplastic anemia, agranulocytosis, hypogammaglobulinemia) and proliferative (American Burkitt's lymphoma, immunoblastic sarcoma of B-cells, fatal infectious mononucleosis, plasmocytoma) phenotypes (Purtilo et al. 1979). This immunodeficiency may occur sporadic or clustered in certain families. Purtilo et al. $(1975,1977)$ reported two families of which approximately half the boys exhibited subtle progressive immunodeficiency to EBV and other viruses. About $40 \%$ of the affected boys have developed malignant lymphoma, $40 \%$ fatal infectious mononucleosis, and $20 \%$ dysgammaglobulinemia. Most of these phenotypes are associated with EBV infection and can be considered to be complications of infectious mononucleosis (Purtilo et al. 1979). Bar et al. (1974) reported another family of which four male cousins died of a fulminating lymphoproliferative disease associated with EBV infection. Virelizier et al. (1978) described persistent EBV-infection with hypergammaglobulinemia and fatal immunoblastic proliferation in a 5-year-old girl with defective immune interferon secretion. Crawford et al. (1979) reported fatal acute infectious mononucleosis in a 34-year-old man with T-cell depletion. Other cases of fatal infectious mononucleosis were not associated with detectable immune defects (Britton et al. 1978; Veltri et al. 1978). Also the observation of so-called Burkitt-type leukemia (Stevens et a1. 1972; Clift et al. 
1963) is an interesting observation in this context, though the majority of the American Burkitt cases are EBV-negative.

The underlying mechanisms for malignant transformation of infectious mononucleosis are still unclear. But evidence accumulates suggesting that a graft-versus-host-disease-like reaction (Gleichmann et al. 1972) is triggered by altered surface antigens of EBV-infected B-lymphocytes. Monoclonal malignant cell growth would then occur after a cytogenetic change, e.g. a 8:14 chromosomal translocation as observed in Burkitt lymphoma and some other B-cell lymphomas (Klein, personal communication).

We report here the serological, clinical and hematological features of three patients, in whom serologically confirmed recent infectious mononucleosis is followed by fatal lymphoproliferation (case 1), and by definite (case 2) and probable (case 3 ) acute monocytic leukemia. A short note on cases 2 and 3 has been published elsewhere as letter to the editor (Hehlmann et al. 1980).

\section{Case Reports}

\section{Case 1}

This 61-year-old previously healthy woman complained of sore throat, weakness and intermittent fever for 3 weeks. In addition, she had a generalized exanthema, abdominal pain in the left lower quadrant, and obstipation for two weeks. She was treated by her family physician for tonsillitis and became afebrile. Four days before admission she noted a painful swelling of her cervical, nuchal, inguinal, and right supraclavicular lymphnodes and became febrile again.

On admission on Aug. 13, 1968 she had massive painful swelling of her cervical, nuchal, inguinal, and right supraclavicular lymphnodes, her tonsils were enlarged, inflamed, and purulent, and were covered with fibrine. Her spleen was palpable below the left costal margin, her liver size was normal. Her temperature was $38^{\circ} \mathrm{C}$ and her body weight $55 \mathrm{~kg}$. Laboratory tests showed monocytosis and absolute lymphopenia. Her leukocytes were $6,800 / \mu \mathrm{l}$ with $50 \%$ neutrophils, $13.5 \%$ bands, $7.5 \%$ eosinophils, $1 \%$ basophils, $13 \%$ monocytes, $11.5 \%$ lymphocytes, and $3.5 \%$ plasma cells. Repeat blood counts showed up to $23 \%$ monocytes with persisting lymphopenia. Lymphocytes were small and rarely of monocytoid morphology. Total serum protein was $8.2 \mathrm{~g} / \mathrm{dl}$ with $43.6 \%$ albumin, $3.8 \% \alpha_{1}, 10.1 \% \alpha_{2}, 10.8 \% \beta$ and $31.7 \% \gamma$-globulin. Immune electrophoresis showed an increase of $\mathrm{IgG}$, IgA, and $\operatorname{IgM}$. Sedimentation rate was $55 \mathrm{~mm}$. All other laboratory tests were normal. A Paul-Bunnell
Table 1. Clinical and hematological features of the three patients

\begin{tabular}{llll}
\hline Feature & Case 1 & Case 2 & Case 3 \\
\hline Fever & + & - & + \\
Lymphadenomegaly & + & - & + \\
Sore throat & + & + & - \\
Hepatosplenomegaly & - & + & - \\
Splenic rupture & - & + & - \\
Lymphocytosis & - & - & + \\
Atypical mononuclear cells + & + & + \\
in the peripheral blood & & & \\
Hypergammaglobulinemia & + & + & + \\
Elevated IgM & + & + & - \\
Type of malignancy & malignant & acute & acute \\
& lymphoma & monocytic & monocytic \\
& & leukemia & leukemia \\
\hline
\end{tabular}

Table 2. Serological features of patient 1

\begin{tabular}{llll}
\hline & $\begin{array}{l}\text { Heterophil } \\
\text { antibodies } \\
\text { (Paul Bunnell) }\end{array}$ & $\begin{array}{l}\text { Cyto- } \\
\text { megalo- } \\
\text { virus }\end{array}$ & $\begin{array}{l}\text { Sabin-Feldman } \\
\text { dye test for } \\
\text { toxoplasmosis }\end{array}$ \\
\hline Aug. 14, 1968 & negative & $1: 40$ & $1: 10$ \\
Aug. 28, 1968 & $1: 160$ & $1: 20$ & $1: 100$ \\
Sept. 4, 1968 & 1:160 & $1: 20$ & $1: 100$ \\
Nov. 1968 & negative & N.D. & N.D. \\
Dec. 30,1968 & negative & negative & $1: 256$ \\
Feb. 25, 1969 & N.D. & N.D. & $1: 10$ \\
\hline
\end{tabular}

N.D. $=$ not done

agglutination was negative on Aug. 14, and 1:160 on Aug. 28 and on Sept. 4 (compare Table 2). No EBV-serology was available at that time. A SabinFeldmann test for toxoplasmosis was positive 1:10 on Aug. 14, and 1:100 on Aug. 28 and Sept. 4. Serological tests for cytomegalo- and adenoviruses were non-contributory. A bone marrow aspirate taken on Aug. 19 showed raised plasma and lymphoid cells. Cervical lymph node biopsies of Aug. 22 and Aug. 28 showed unspecific lymphadenitis.

The further hospital course was unremarkable. The lymphnode swelling regressed, the patient became afebrile without specific therapy, and the differential blood count normalized. The ESR remained elevated at $55 \mathrm{~mm}$. The diagnosis was infectious mononucleosis, and the patient was discharged on Sept. 6 .

She felt relatively well until the end of October when she again complained of low grade fever up to $38.5^{\circ}$, fatiguability, malaise, and diffuse headache. She had cough productive of whitish sputum. Her lymphnodes which had never completely regressed to normal increased in size and became painful again, and she again developed a fibrinous tonsillitis. Her family doctor found an increase of the ESR to $92 \mathrm{~mm}$ 
and marked monocytosis. Paul-Bunnell agglutination and serology for diphtheria were negative. She was readmitted on Dec. 27 with massive painful swelling of her cervical, supraclavicular, axillary, and inguinal lymph nodes. The lymphnodes were firm, smooth, and movable. Her tonsils were enlarged, purulent, and covered with fibrin. She had a normal sized liver and a non-palpable spleen. Her body weight had decreased to $48 \mathrm{~kg}$. Laboratory tests showed a $\mathrm{Hb}$ of $11.8 \mathrm{~g} / \mathrm{dl}, 6,800$ leucocytes $/ \mu 1$ with $44 \%$ neutrophils, $13 \%$ bands, $0.5 \%$ myelocytes, $3.5 \%$ eosinophils, $0.5 \%$ basophils, $21.5 \%$ monocytes, $16.5 \%$ lymphocytes, and $0.5 \%$ plasma cells. There were some monocytoid lymphocytes. Total serum protein was $8.5 \mathrm{~g} / \mathrm{dl}$ with $38.5 \%$ albumin, $4.3 \% \alpha_{1}, 10.3 \% \alpha_{2}, 6.8 \% \beta$, and $40.1 \% \gamma$-globulin. Immunoelectrophoresis showed increased $\operatorname{IgG}$ and markedly increased $\operatorname{IgA}$ and $\operatorname{IgM}$. A bone marrow aspirate showed a marked increase of plasma cells, mostly small mature forms, and no sign for lymphoma or leukemia. A throat culture was negative for $C$. diphtheriae and hemolytic str., group A. Paul-Bunnell agglutination and serological tests for adenoviruses and cytomegalovirus were negative. Sabin-Feldman dye-test for toxoplasmosis was positive (1:256). A chest $x$-ray and a spleen szintigram were normal. A lymphography showed enlarged, pathological iliac, pelvic, and paraaortic lymph nodes with filling defects and partial destructions. There was no filling of lymphatics above the second lumbar vertebra. A biopsy of the right tonsil taken on Dec. 28 was initially interpreted as transitional cell carcinoma. A reevaluation, however, together with a subsequent biopsy of a right inguinal lymphnode taken on Jan. 3, 1969, allowed the diagnosis of infectious mononucleosis (Lennert, personal communication). The lymphnodes continued to increase in size and the patient remained febrile. A blood count of Jan. 14 showed a $\mathrm{Hb}$ of $13.1 \mathrm{~g} / \mathrm{dl}$ and 7,800 leukocytes $/ \mu \mathrm{l}$ with $21 \%$ neutrophils, $34 \%$ bands, $0.5 \%$ metamyelocytes, $0.5 \%$ myelocytes, $15.5 \%$ monocytes, $20 \%$ lymphocytes, and $8.5 \%$ plasma cells. Again there were atypical monocytes. On Jan. 20, radiotherapy to the enlarged lymphnodes was started which was tolerated poorly. After 1,250 rad in small doses irradiation was terminated because of lymph edema and ulceration. Prednison, $50 \mathrm{mg} /$ day was started. Laboratory tests of Feb. 26 revealed raised values of transaminases, bilirubin, and alkaline phosphatase, a drop of the prothrombin time, and a $\mathrm{Hb}$ of $9.1 \mathrm{~g} / \mathrm{dl}$. Liver involvement and gastrointestinal bleeding were suspected. She died on Feb. 28, 1969 from cardiovascular collapse. The autopsy revealed extensive malignant lymphoma involving the cervical, supra- and infraclavicular, axillary, paraaortic, and inguinal lymph nodes, several old and fresh pulmonary emboli, and a bleeding gastric ulcer as immediate cause of death.

\section{Case 2}

This 72-year-old previously healthy man came to the Medizinische Poliklinik because of fatiguability, weakness, loss of appetite, sore throat, and pain in the fingers and wrists for about four weeks. On physical examination performed on Oct. 30, 1978, he was afebrile and appeared generally well except for an enlarged liver of $14 \mathrm{~cm}$ in $\mathrm{MCL}$. No lymph nodes and no spleen were palpable. Laboratory tests on Oct. 23 had shown a leukocytosis of $17,900 / \mu$ l with $35 \%$ neutrophils, $12 \%$ bands, $3 \%$ metamyelocytes, $7 \%$ lymphocytes, $42 \%$ monocytes and $1 \%$ basophils. Serum creatinine was $2.0 \mathrm{mg} / \mathrm{dl}$, uric acid $7.3 \mathrm{mg} / \mathrm{dl}$, total serum protein $8.3 \mathrm{~g} / \mathrm{d}$ l with $58.6 \%$ albumin, $3.2 \% \alpha_{1}, 5.9 \% \alpha_{2}, 9.2 \% \beta$ and $23.2 \% \gamma$-globulin. Quantitative $\operatorname{Ig}$ determination showed elevated $\operatorname{IgG}$ and IgM-levels (IgG 4,000 mg/dl, IgA $400 \mathrm{mg} / \mathrm{dl}$, IgM $412 \mathrm{mg} / \mathrm{dl}$ ). All other laboratory tests including alkaline phosphatase, bilirubin, and transaminases were normal. A repeat blood count on Oct. 30 revealed 24,600 leukocytes $/ \mu$ with $31 \%$ neutrophils, $20 \%$ bands, $3 \%$ metamyelocytes, $1 \%$ myelocytes, $9 \%$ lymphocytes, $3 \%$ eosinophils, $1 \%$ basophils, and $33 \%$ monocytoid, atypical mononuclear cells. Serological tests for $\mathrm{EB}$ virus gave the following titers: anti-EBV (VCA) IgG 1:512, anti-EBV (VCA) IgM 1:16, antiEBV (EA) IgG $1: 20$, anti-EBNA IgG negative (compare Table 3). Paul-Bunnell agglutination was negative. Hepatitis, ECHO, Coxsackie, and Rubella sero-

Table 3. EBV-Serology of patients 2 and 3

\begin{tabular}{ll|lll}
\hline & Patient 2 & \multicolumn{3}{|c}{ Patient 3 } \\
\hline & Nov. 2,78 & Nov.9,78 & Nov.23, 78 & Dec. 20,78 \\
Anti-EBV (VCA)-IgG & $1: 512$ & $1: 256$ & $1: 128$ & $1: 128$ \\
Anti-EBV (VCA)-IgM & $1: 16$ & $1: 32$ & negative & negative \\
Anti-EBV (EA)-IgG & $1: 20$ & negative & negative & $1: 4$ \\
Anti-EBNA-IgG & negative & negative & negative & negative \\
\hline
\end{tabular}

a Rheumatoid factor removed by preabsorption with IgG-coated latex particles

b Lowest dilution tested $1: 3$ 
logies were non-contributory. A sonogram of the abdomen revealed a border-line enlarged spleen of $10 \times$ $6 \mathrm{~cm}$ and a liver of $12 \mathrm{~cm}$ in MCL. A chest X-ray was unremarkable. During the following days the leukocytosis increased, and the patient became febrile and thrombocytopenic (temperatures up to $38.6^{\circ} \mathrm{C}$ ). In addition to smaller atypical mononuclear cells (Fig. 1 A), large, bizarre blast cells appeared (Fig. 1 B). On Nov. 7 he was admitted to another hospital. He was icteric, his pulse rate was 116 per minute, his blood pressure was $110 / 70$. The liver was $16 \mathrm{~cm}$ in MCL, the spleen was not palpable. The leukocytes had risen to $98,000 / \mu \mathrm{l}$ with more than $90 \%$ atypical mononuclear cells, the platelet count was $21,000 / \mu 1$. Creatinine was $2.7 \mathrm{~g} / \mathrm{dl}$, uric acid $10.2 \mathrm{mg} / \mathrm{dl}$, bilirubin $3.4 \mathrm{mg} / \mathrm{dl}$, transaminases slightly raised. A bone-marrow aspirate taken on Nov. 8 showed monocytic leukemia with $76 \%$ immature monoblasts (esterase positive) containing many nucleoli, large cytoplasmic vacuoles, and a fine chromatin pattern, some lymphoid and plasma cells, almost no mature neutrophils, reduced erythropoiesis, and reduced numbers of megakaryocytes (Fig. 2). Soon after admission he went into shock with left upper quadrant pain. Splenic rupture was suspected. A cytostatic therapy with vincristine and arabinosylcytosine was started. Four days later he went into shock again. He had had a large hemorrhage into the peritoneal cavity, compatible with splenic rupture. Intravascular coagulation and paralytic ileus developed, and the patient died from severe hemorrhagic diathesis on Nov. 20. Permission for autopsy was refused.

\section{Case 3}

This 71-year-old previously healthy woman complained of malaise, fever, and a painful lump in her right axilla for several weeks. Examination on admission on Oct. 26, 1978 showed an obese patient with a normal sized liver and a nonpalpable spleen. There was a cherry-sized lump in the right axilla.

Her $\mathrm{Hb}$ was $10.4 \mathrm{~g} / \mathrm{dl}$; her leukocyte count was $8,600 / \mu 1$ with $8 \%$ neutrophils, $23 \%$ bands, $36 \%$ lymphocytes, and $33 \%$ monocytes. Serum electrophoresis showed a normal total serum protein with $47.5 \%$ albumin, $5 \% \alpha_{1}, 10 \% \alpha_{2}, 10 \% \beta$, and $27.5 \% \gamma$-globulin. The ESR was raised to $96 \mathrm{~mm}$, creatinine was $1.9 \mathrm{mg} / \mathrm{dl}$, uric acid $12.4 \mathrm{mg} / \mathrm{dl}$. All other laboratory values were unremarkable. During the next two weeks her $\mathrm{Hb}$ dropped to below $7 \mathrm{~g} / \mathrm{dl}$. On Nov. 15 her leukocytes were $3,700 / \mu \mathrm{l}$ with $90 \%$ lymphocytes, $2 \%$ monocytes, $5 \%$ neutrophils, $2 \%$ bands, and $1 \%$ eosinophils. Her albumin was $45 \%, \alpha_{1}$-globulin $4.5 \%$, $\alpha_{2}$-globulin $7,5 \%, \beta$-globulin $10 \%$, and $\gamma$-globulin
$33 \%$. Immunoelectrophoresis showed polyclonal increase of $\operatorname{IgG}$ and $\operatorname{IgA}(\operatorname{IgG}>4,000 \mathrm{mg} / \mathrm{dl}$, IgA $462 \mathrm{mg} / \mathrm{dl}, \operatorname{IgM} 125 \mathrm{mg} / \mathrm{dl}$ ). A bone marrow aspirate taken on Nov. 9 showed acute probably monocytic leukemia (Fig. 3). PAS was intermediate, peroxydase negative, esterase not done. Serological tests for EB virus done on Nov. 9 gave the following titers: antiEBV (VCA) IgG 1:256, anti-EBV (EA) IgG negative, anti-EBV (VCA) IgM 1:32, anti-EBNA-IgG negative. Two weeks later the titers were: anti-EBV (VCA) IgG $1: 128$, anti-EBV (EA) IgG negative, anti-EBV (VCA) IgM now negative, and again anti-EBNA-IgG negative (see Table 3). Paul-Bunnell agglutination was negative. No antibodies against mumps, cytomegalovirus, and adenoviruses were detected. A histological examination of the enlarged lymphnode from the right axilla was unremarkable without signs of infiltration. The patient was treated with 6-mercaptopurine and prednison for twenty days which was terminated because of leukopenia and thrombocytopenia. The thrombocytopenia persisted, the leucocyte count reached 70,000 , and the dysproteinemia worsened. The quantitative immunoelectrophoresis showed persisting IgG elevation. A bone-marrow picture on Dec. 20 was unchanged. An EBV serology was also unchanged except for an anti-EBV (EA) IgG of now $1: 4$. She died on Dec. 28 of a cardiac arrest. An autopsy was not permitted.

\section{Results}

The clinical and laboratory features of the three patients are summarized in Tables 1 to 3 . Patient 1 had the typical features of infectious mononucleosis: sore throat, fever, lymphadenomegaly, malaise, atypical lymphocytes, hypergammaglobulinemia with raised IgM, and positive Paul-Bunnell agglutination. The development of malignant lymphoma in this patient is compatible with unlimited B-cell proliferation secondary to EBV-infection.

Patient 2 showed several clinical features characteristic of infectious mononucleosis: sore throat, malaise, hepatosplenomegaly, atypical monocytoid cells, hypergammaglobulinemia, and terminally, as described for a number of fatal cases of infectious mononucleosis, splenic rupture. The white cell morphology was compatible, in part, with proliferating lymphoid cells masquerading as monocytes (Purtilo, personal communication). Patient 3 had clinical features suggestive of infectious mononucleosis: malaise, a painful lump in her axilla, lymphocytosis, and hypergammaglobulinemia with raised IgM. Patients 2 and 3 had a positive EBV-serology diagnostic of recent, 1-2 months old EBV-infection. Both patients developed clinically overt leukemia shorthly after EBV infection. In both 


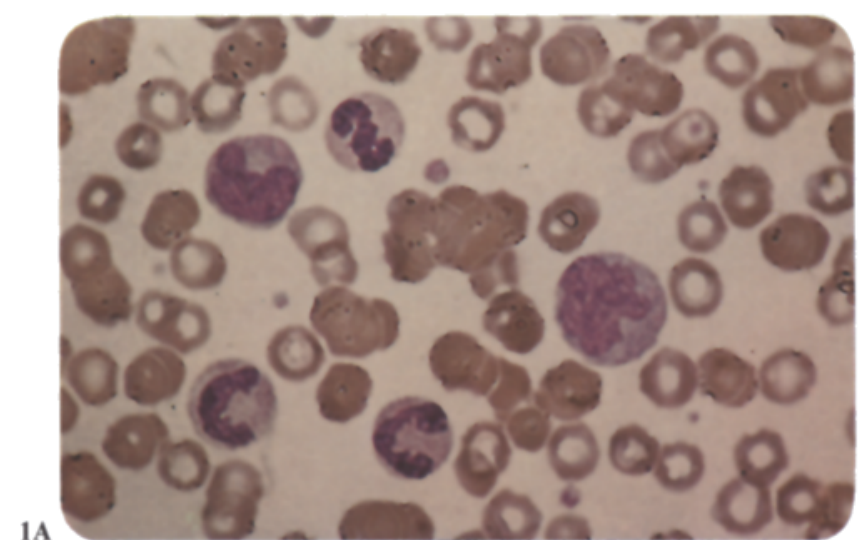

$1 \mathrm{~A}$
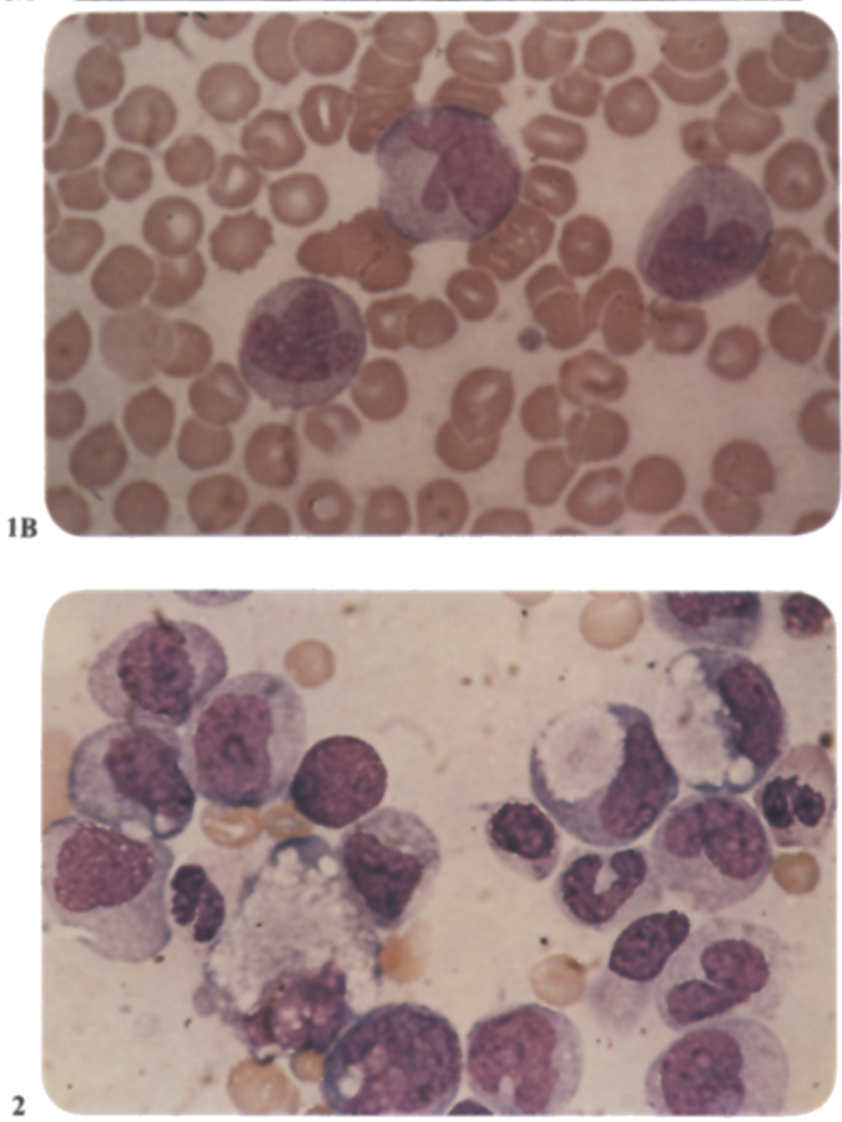

patients the type of leukemia appeared to be monocytic (compare Figures 2 and 3), although an esterase reaction was not done in case 3 . The cause of death of patient 2 was shock probably as a consequence of splenic rupture (gross blood in the peritoneal cavity). The cause of death of patient 3 was cardiac arrest probably as a consequence of bone-marrow invasion and CNS involvement by the acute leukemia.

\section{Discussion}

We report here three elderly patients with serologically confirmed recent infectious mononucleosis who
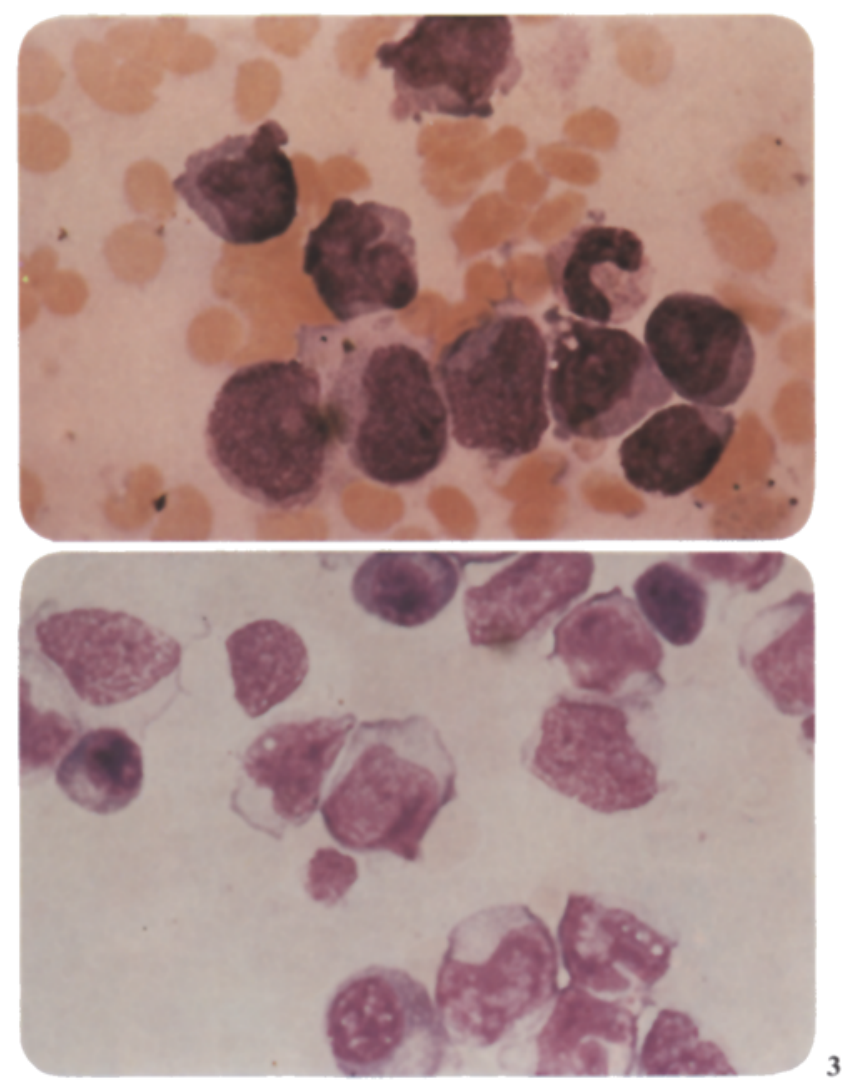

Fig. 1. A Peripheral blood smear Nov. 2, 1978 (case 2) B Peripheral blood smear Nov. 6, 1978 (case 2)

Fig. 2. Bone marrow aspirate of case 2 (Nov. 8, 1978)

Fig. 3. Bone marrow aspirate of case 3 (Nov. 9, 1978)

succumbed to malignancies of the lymphatic or monocytic/phagocytic systems. In case 1, clinical features (fever, sore throat, malaise, lymphadenomegaly, atypical lymphocytes, hypergammaglobulinemia with raised $\operatorname{IgM}$ ), serological tests (positive Paul-Bunnell agglutination), and histological data (plasmocytosis and increased numbers of lymphoid cells in bone marrow and lymphnodes), leave little doubt about infectious mononucleosis terminating in fatal lymphoproliferation. Similar courses of fatal infectious mononucleosis and of B-cell lymphoproliferation have been described in males of families with probable or definite X-linked immune deficiency disorders (Bar et al. 1974; Purtilo et al. 1975; Purtilo et al. 1977) as well as in sporadic cases with defects in cell-mediated immune responses (Crawford et al. 1979; Robinson et al. 1980; Thestrup-Pedersen et al. 1980), with defective immune interferon secretion (Virelizier et al. 1978), or with unknown defects (Britton et al. 1978); Veltri et al. 1978). In case 2, clinical features (sore throat, malaise, hepatosplenomegaly, monocytosis with atypical monocytoid cells, hy- 
pergammaglobulinemia with raised $\operatorname{IgM}$ ) were suggestive of infectious mononucleosis. Infectious mononucleosis in the elderly, however, is rare, and little is known on the variability of clinical features of this disease in old age. EBV-serology with positive anti-EBV (VCA) IgM and negative anti-EBNA-IgG is compatible with the diagnosis of a recent, 4 to 8 weeks old EBV infection in this patient.

In case 3 , clinical features (malaise, fever, painful lump in the axilla, lymphocytosis, hypergammaglobulinemia) were compatible with, but not diagnostic of, infectious mononucleosis. But also here EBV serology (see Table 3) allowed the diagnosis of a recent EBVinfection preceding hospital admission by $4-6$ weeks.

The causal relationship between infectious mononucleosis and unlimited B-cell proliferation in immune deficient persons is now recognized (for review see Purtilo 1979, 1980). In case 1, an immune deficiency was not demonstrated, since cellular immunity was not assessed in our patients. Infectious mononucleosis progressing to leukemia has not been described though infectious mononucleosis preceding or following acute leukemia in children and young adults has been observed (Freedman et al. 1970; Stevens et al. 1971; Levine et al. 1972; Langenhuysen et al. 1974; Pedersen et al. 1975). Since infectious mononucleosis in the elderly and acute monocytic leukemia are both rare conditions, a causal relationship of these two conditions has to be considered. This relationship might have remained unnoticed probably because the clinical features of monocytic leukemia generally have not suggested infectious mononucleosis, and therefore serological tests were not done. As a differential diagnosis a fulminating infectious mononucleosis masquerading as acute monocytic leukemia (Purtilo, personal communication) should be considered also. This view is supported by the white cell morphology and by elevated immunoglobuline levels. A further alternative is that pre-existing but not yet diagnosed acute leukemia was predisposing to infection with EB virus. We would favor, however, the reverse sequence, since infectious mononucleosis in both patients, as estimated by serology, probably preceded clinically overt leukemia by 1 to 2 months and since it is known that infectious mononucleosis in immune deficient hosts can run a fulminating course (Purtilo 1979). No tests, however, were done to assess cell mediated immunity in these elderly patients to prove our assumption. It appears that in future cases of acute monocytic leukemia serological tests for EBV and an assessment of immune competence should be carried out.

Acknowledgements. We thank Drs. D. Huhn, H. Theml, W. Kaboth, and H.H. Edel, München, and Dr. A. Puzik, Indersdorf, for their contributions of patient information and laboratory data.

\section{References}

Aung MK, Krueger GG, Feorino PM, Smith CB (1978) Splenic rupture due to infectious mononucleosis. JAMA 240:1752-1753

Bar RS, DeLor CJ, Clausen KP, Hurtubise P, Henle W, Hewetson JF (1974) Fatal infectious mononucleosis in a family. N Engl J Med 290:363-367

Britton S, Andersson-Anvret M, Gergely P, Henle W, Jondal M, Klein G, Sandstedt B, Svedmyr E (1978) Epstein-Barr-Virus immunity and tissue distribution in a fatal case of infectious mononucleosis. N Eng1 J Med 298:89-92

Carter RL (1975) Infectious mononucleosis: model for self-limiting lymphoproliferation. Lancet 1.:846-849

Clift RA, Wright DH, Clifford P (1963) Leukemia in Burkitt's lymphoma. Blood 22:243-251

Crawford DH, Epstein MA, Achong BG, Finerty S, Newman J, Liversedge S, Tedder RS, Stewart JW (1979) Virological and immunological studies on a fatal case of infectious mononucleosis. J Infect $1: 3748$

Epstein MA, Achong BG (1977) Pathogenesis of infectious monoaucleosis. Lancet $2: 1270-1273$

Freedman MH, Gilchrist GS, Hammond GD (1970) Concurrent infectious mononucleosis and acute leukemia. JAMA $214: 1677-1680$

Gleichmann E, Gleichmann H, Schwartz RS (1972) Immunologic induction of malignant lymphoma: Genetic factors in the graftversus-host model. J Natl Cancer Inst 49:793-804

Grose C, Henle W, Henle G, Feorino PM (1975) Primary EpsteinBarr virus infections in acute neurologic diseases. $N$ Engl $J$ Med 292: 392-395

Hehlmann R, Walther B, Zöllner N, Wolf H, Deinhardt F (1980) Infectious mononucleosis and Acute Monocytic Leukemia. Lancet 2:652-653

Henle W, Henle G, Diehl V (1968) Relation of Burkitt's tumorassociated herpes-type virus to infectious mononucleosis. Proc Natl Acad Sci USA 59:94-101

Langenhuysen MMAC (1974) Concurrent infectious mononucleosis and acute myelocytic leukemia. Acta Haematol 51:121-127

Levine PH, Stevens DA, Coccia PF, Dabich L, Roland A (1972) Infectious mononucleosis prior to acute leukemia: A possible role for the Epstein-Barr virus. Cancer 30:875-880

Mangi RJ, Niederman JC, Kelleher JE Jr, Dwyer JM, Evans AS, Kantor FS (1974) Depression of cell-mediated immunity during acute infectious mononucleosis. N Engl J Med 291:11491153

Pattengale PK, Smith RW, Perlin E (1974) Atypical lymphocytes in acute infectious mononucleosis. Identification by multiple $\mathrm{T}$ and B lymphocyte markers. N Engl J Med 291:1145-1148

Pedersen PR, Gerber P, Sweeney G, Blom J (1975) Infectious mononucleosis preceding acute myelomonocytic leukemia. Am J Med Sci $269: 131-135$

Penman HG (1970) Fatal infectious mononucleosis: A critical review. J Clin Pathol 23:765-771

Provisor AJ, Iacuone JJ, Chilcote RR, Neiburger RG, Crussi FG, Baehner RL (1975) Acquired agammaglobulinemia after a lifethreatening illness with clinical and laboratory features of infectious mononucleosis in three related male children. $\mathrm{N}$ Eng! J Med 293:62-65

Purtilo DT, Yang JPS, Cassel CK, Harper R, Stephenson SR, Landing BH, Vawter GF (1975) X-linked recessive progressive combined variable immunodeficiency (Duncan's disease). Lancet 1:935-941

Purtilo DT, DeFlorio D Jr, Hutt LM, Bhawan J, Yang J, Otto R, Edwards W (1977) Variable phenotypic expression of an X-linked recessive lymphoproliferative syndrome. N Engl J Med 297: 1077-1081

Purtilo DT (1977) Opportunistic Non-Hodgkin's lymphoma in X- 
linked recessive immunodeficiency and lymphoproliferative syndromes. Sem in Oncol 4:335-343

Purtilo DT, Paquin L, DeFlorio D, Virzi F, Sakhuja R (1979) Immunodiagnosis and immunopathogenesis of the X-linked recessive lymphoproliferative syndrome. Sem in Hema tol 16:309343

Purtilo DT (1980) Epstein-Barr-Virus-induced oncogenesis in immune-deficient individuals. Lancet $2: 300-303$

Purtilo DT (1981) Immunopathology of infectious mononucleosis and other complications of Epstein-Barr virus infections. In: Sommers S, Rosen P (eds) Pathology Annual 1980. AppletonCentury-Crofton, New York (in press)

Robinson JE, Brown N, Andiman W, Halliday K, Francke U, Robert MF, Andersson-Anvret M, Horstmann D, Miller $G$ (1980) Diffuse polyclonal B-cell lymphoma during primary in fection with Epstein-Barr-Virus. N Engl J Med 302:1293-1297

Stevens DA, Levine PH, Lee SK, Sonley MJ, Waggoner DE (1971) Concurrent infectious mononucleosis and acute leukemia: Case reports. Review of the literature and serologic studies with the Herpes-type Virus (EB Virus). Am J Med 50:208-217

Stevens DA, O'Conor GT, Levine PH, Rosen RB (1972) Acute leukemia with "Burkitt"s Lymphoma Cells" and Burkitt's Lymphoma: simultancous onset in American siblings; description of a new entity. Ann Intern Med 76:967-973
Thestrup-Pedersen K, Esmann V, Jensen JR, Hastrup J, Thorling K, Saemundsen AK, Bisballe S, Pallesen G, Madsen M, GraziaMasucci M, Ernberg I (1980) Epstein-Barr-Virus-induced lymphoproliferative disorder converting to fatal Burkitt-like lymphoma in a boy with interferon-inducible chromosomal defect. Lancet 2:997-1002

Veltri RW, McClung JE, Sprinkle PM (1978) Detection of EpsteinBarr virus-coded antigens in the $\mathrm{C} 3$ receptor bearing lymphocyte subpopulation of patients with exudative tonsillitis, infectious mononucleosis, and Hodgkin's disease. Int $J$ Cancer $21: 683-687$

Virelizier L, Lenoir G, Griscelli C (1978) Persistent Epstein-Barr Virus infection with hypergammaglobulinemia and immunoblastic proliferation associated with a selective defect in immune interferon secretion. Lancet 2:231-234

Received December 10, 1980

Accepted January 23, 1981

PD Dr. R. Hehlmann

Med. Poliklinik der Universität

Pettenkoferstr. 8 a

D-8000 München 2

Federal Republic of Germany 